\title{
A Water Conservation \& Development Project in the Yorkton Area
}

by C. J. Houston, Yorkton

In the vicinity of Yorkton there lies an area of marsh land which offers unique possibilities for multipurpose use through such an arrangement under the Agricultural Rehabilitation and Development Act.

The area concerned is shown on the accompanying map. It consists of five lakes-upper and lower Rousay Lakes (5), York Lake (6), Leach Lake (4), Crescent Lake (3), and the adjoining marsh or "wet landis" area (1 and 2). It extends from \#10 Highway, seven miles west of Yorkton, and cuts \#9 Highway 14 miles south. It is one of the best remaining examples of a "wetlands area" in Saskatchewan.

The project involves further water diversion into the area, for example, from Sorefoot Creek, and establishing dams, dykes, and controls, for the dual purpose of holding water in the area, and to prevent flooding of adjacent farm land by providing drainage in the wet years. This area has considerable potential for better agricultural use. It has a wider untapped potential in other fields related to water, wild life, and recreation.

In the past decade this area has been subject to great fluctuations in water levels, and hence drastic variations in agriculture, and those other uses which change with water levels. The new proposal is to stabilize water levels and thus conserve our natural resources.

In Canada our whole attitude and sense of values is changing. From a young country profligate in its waste of resources, we have come to realize that we are running short of many of our native sources of wealth. "Conservation" and "orderly development" are the essential slogans of the future.

To every dweller on these prairies the most obvious resource requiring conservation is water. Water is said to be a nation's most essential natural resource. Lack of water restricts the development of every community. The Central Plains region of this continent is said to be fast reach- ing the peak of its development as limited by this one resource-water.

In Saskatchewan and other Prairie Provinces much study is now being given to the better use of our main sources of supply. To the south of us governments not only seek to preserve their present resources, but spend millions of dollars to reclaim areas which once were drained for agricultural purposes. There is general agreement among conservationists that the nation is best served when many of the areas known as "marshlands" or "wetland areas" are preserved or reclaimed.

To return to the Yorkton projectOur primary object is to stabilize water levels and thus increase the resources of the area. These resources can be placed in four categories: The Water itself, Agriculture, Wild Life, and Recreation.

I propose to list a few of the benefits from development in these. four directions.

First of all there is the water itself The presence of such large bodies of surface water should improve the water tables in the soil-and indeed help guarantee the wells of an expanding Yorkton City. The holding and storage of water in the upper branches of the Assiniboia is an essential of flood control, and benefits even the Red River control at Winnipeg. To quote Dr. T. A. Patrick, one of Saskatchewan's first conservationists, "The water is needed here, not in Hudson Bay." A stable and fairly constant supply of water is the prime essential to permit consistent use ano development of the area in all its aspects.

The benefits conferred on agriculture by relief from alternating cycles of flood and drought are ap. parent to all. Within this project ares one has witnessed lake bottoms dry and cultivated, while a decade late: the land for miles about is flooded Sporadic attempts to farm margina land have lost out to weeds and volunteer vegetation. A more stable water suppy could avoid all this anc permit better and more consisten 
land use. Even as hay lands or community pastures the returns should be most rewarding.

The wild life potential of the area has been well demonstrated and documented. Ducks Unlimited include much of this area in what they call the "Illinois Project". Their surveys are exhaustive, and they have already spent a considerable sum on its improvement as a "duck factory". They have a continuing interest and an expressed desire to co-operate in every way possible. The area is an exceptionally fine waterfowl area, when water is present. The men with the know-how are already on the spot.

Saskatchewan's oldest industry, the fur trade, depends on the prevalence of water. The beaver, mink, and muskrat have always been the backbone of that trade. Of recent years accurate figures are available as to the fur catch in this area of marshes. It is interesting to note that in the peak year of the 1950's the catch was 20,000 rats. For the five best years of that cycle it averaged 15,000 per year. For the next five years it averaged 8,000 skins per year. Over the ten year period this is a total of 115,000

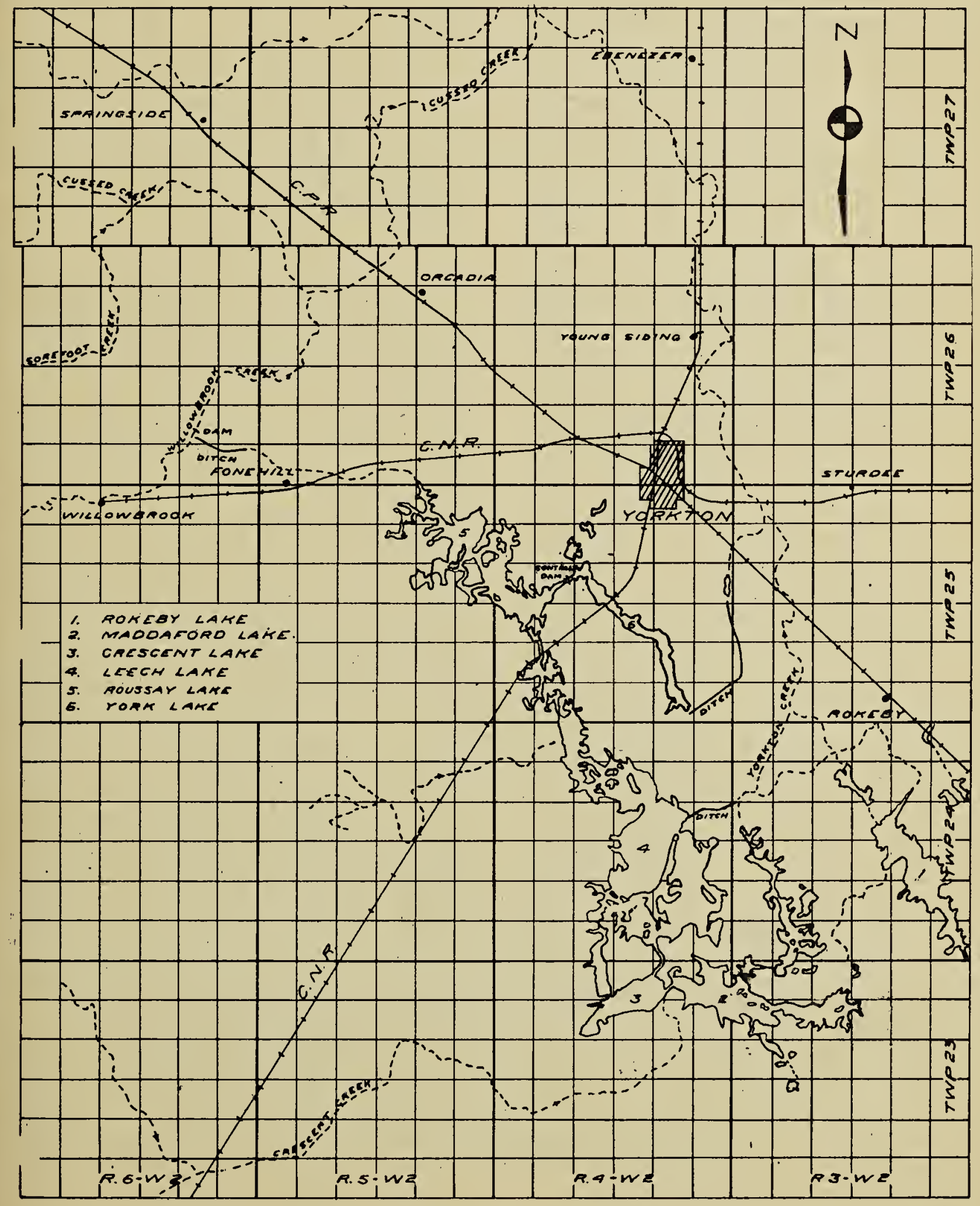

Yorkton Water Conservation and Development Project. 
muskrats, with a total value in excess of $\$ 230,000$. This one crop offers financial justification for the entire project.

The people who received this fur money lived nearby. They are farmers, Indians and Metis. I respectfully interject that the rehabilitation of fur-producing areas is a most practical way to rehabilitate our Indian and Metis citizens.

Then comes the matter of recreational use. No other city in Saskatchewan has such recreational possibilities so close to its doorstep. Another city, Melville, is only 13 miles from the project's southern border.

In discussing the wide field of recreation let us consider that hunting and trapping have already been mentioned in the previous paragraphs. Fishing has been quite good in York Lake in the years of adequate water level; for example, one retired couple caught 360 fish during 1958 in York Lake-largest, 9 pounds.

York Lake at its best offered bathing facilities unsurpassed in the province, and enjoyed by thousands each year. This phase of the project is operated by the Kinsmen Club. Camp kitchens, a Boy Scout camp, sports grounds and playground facilities are provided. Sailing, boating and water skiing have been flourishing sports. Some 40 summer cottages are in use. In fact, the York Lake Park area has been develcped into one of the finest waterside recreational areas in the West-closely adjacent to a heavy concentration of people who are already making great use of it. It is forecast that the City of Yorkton will reach a population of 23,000 by the year 2000. It is doubly important to protect this recreation potential for the use of future generations.

At this point it is interesting to look back on local history from the days of settlement in the early 1880's. In 1897 Dr. T. A. Patrick, then a member of the North West Territories Legislature, procurred government help to divert waters of Willowbrook Creek into York Lake. Following the severe drought of the 1930's these lakes and marshes again faded away, and lake bottoms lay dry and parched. Campers and muskrats alike vanished from the scene. The waterfowl reached an all-time low.

At this point Ducks Unlimited became interested. A diversion of
Willowbrook Creek was created north of Fone Hill. Control dams were installed. The result was most gratifying. The next year upper and part of lower Rousay Lakes were filled, and York Lake soon followed, rising as much as ten feet in a single year. In the late forties to the fifties the water levels varied from adequate to a few years of flood levels, and this posed new problems. Today, due to consecutive years of poor spring runoff, the lakes are dangerously low again. The problem persists, but at last there is some prospect of correlating the interests involved and developing this as a multi-purpose project.

From the engineering point of view much of the project's work is already done. Ducks Unlimited have surveyed and assessed the water potential thoroughly. The City of Yorkton retained a noted engineering firm of water source consultants who have made an independent survey of possible future sources for the city water supply. The Conservation and Development Branch of the Saskatchewan Department of Agriculture has done the most intimate and extensive survey of all. At first they were concerned exclusively with agricultural benefits which might result from drainage. Of recent years they have taken the much brcader view of total use and conservation. Their engineers and staff have been most helpful. It is they who have recently completed a most comprehensive survey of the possibility and the probable cost of the project. The Department of Natural Resources and Water Rights Department have also been interested and helpful.

So now we come to the spring of 1963. Is this dream of water conservation and development simply a dream or can it achieve reality? Personally I believe that realization is now possible. For the first time legislation exists at both Federal and Provincial levels which acknowledges the necessity and facilitates the development of such multi-purpase land use and conservation projects. I refer to "A.R.D.A."-The Agricultural Rehabilitation and Development Act.

The question now is this: Can the Yorkton Project qualify for help under such an Act? This new concept of multi-purpose development 
in conservation of our natural resources is in its infancy, but the local committee is anxious that the project be presented to A.R.D.A. for action.

Certainly it is a multi-purpose project that would benefit agriculture, wildlife, water conservation, and recreation.

Certainly it would put much of the many natural resources of the area to better use.

It should benefit the Metis and the Indians, whose original reserve occupies part of the area.

It offers great benefits in recreational use.

It is unique in that it promises financial returns commensurate with the costs involved.

It is unique in that the necessary engineering and assessment have already been done.

The Dominion Director of A.R.D.A. is quoted in the Leader Post of February 7,1963 , as saying that in the early stages of their work a diversity of experimental projects is desired. The Yorkton Water Conservation and Development.. Project would seem an ideal project for implementation under A.R.D.A. It would benefit many thousands of our Saskatchewan citizens, and preserve for those who come after us a small and already rare example. of our natural heritage.

\section{Pattern for a Refuge}

\section{Montana's Charles M. Russell National Wildlife Range}

In these days when natural areas are disappearing, much attention is being focused on parks and refuges where government action has been taken to preserve the native character of the landscape. Sometimes these protected areas are both of his- toric interest and of value as a wildlife haven. Such is the case in the former Fort Peck Range in Montana, recently renamed the Charles $M$. Russell Wildlife Range in honour of Montana's noted naturalist-artist, who died in 1926.

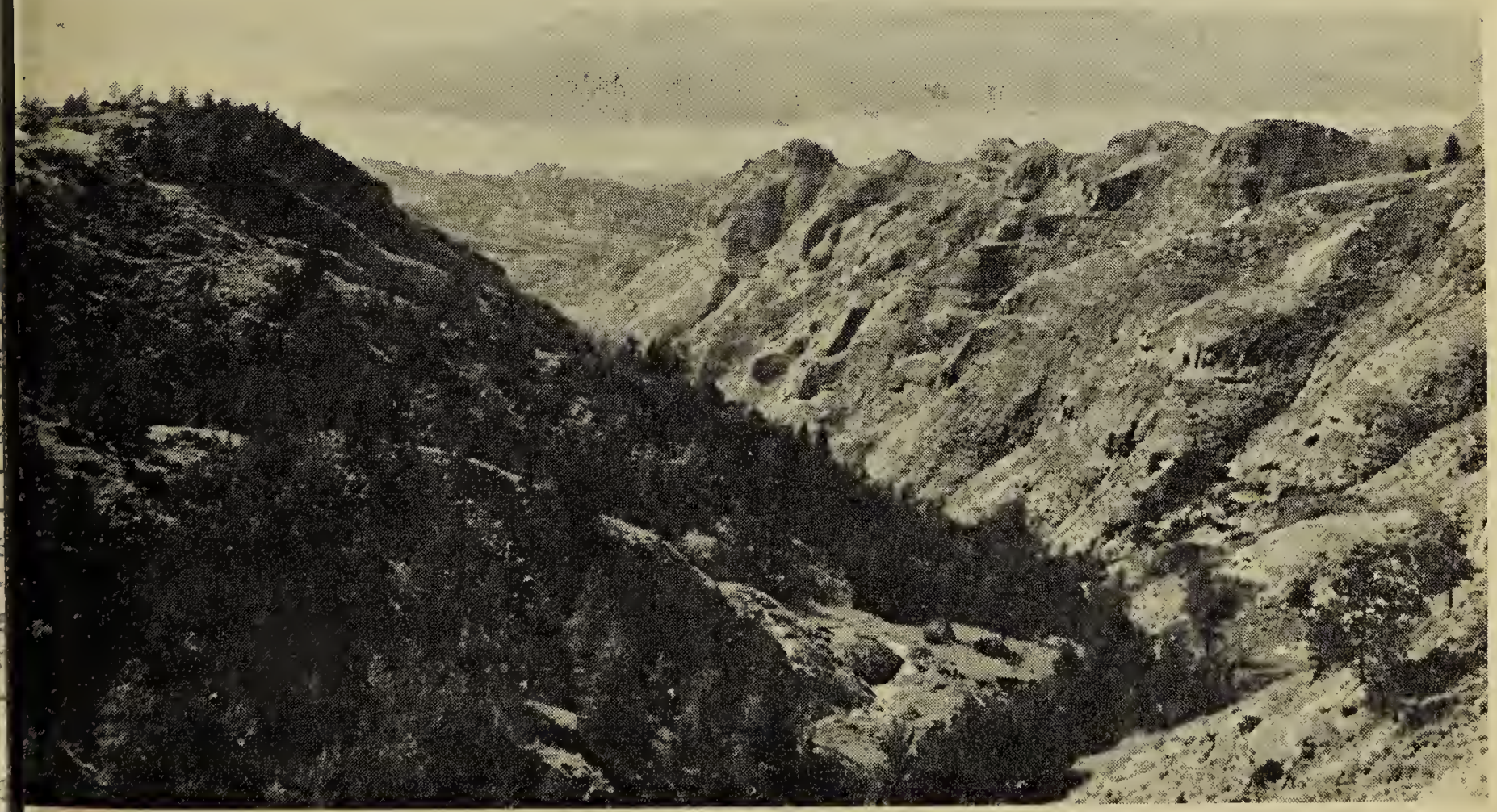

U.S. Department of the Interior Photo. iew of rugged badlands in the Charles M. Russell National Wildlife Range in north Garfield County, Montana. Fort Peck Reservoir in background. 